\title{
New gastropod records from the Cenozoic of Hungary
}

\author{
VICIÁn, Zoltán ${ }^{1}$, KROCK, Helmut² ${ }^{2}$ KovÁCs, Zoltán³ \\ ${ }^{1}$ Hungary, Budapest, Neptun utca 86. 10/42, E-mail: kauri72@gmail.com \\ ${ }^{2}$ Germany, Lüneburg, Julius Leber Str. 8, E-mail: h.krock@ arcor.de \\ ${ }^{3}$ Hungary, Budapest, Kerékgyártó utca 27/A, E-mail: kzkovacszoltan@gmail.com
}

\section{Új adatok a hazai kainozoos gastropodák ismeretéhez}

Összefoglalás

Tanulmányunk a magyarországi kainozoos tengeri molluszkafauna pontosabb megismeréséhez járul hozzá 2 lutetiai, 2 egri és 22 badeni korú Gastropoda-faj leírásával, melyek többsége hazánkból ismeretlen volt, vagy csupán faunalistákon szerepelt. 21 faj új előfordulás Magyarországon, 22 esetében ez az első ábrázolás a hazai szakirodalomban. Bemutatjuk a fajok rétegtani és ôsföldrajzi elterjedését. Közelmúltbeli terepmunkák, valamint a Magyar Természettudományi Múzeum gyújteménye alapján egy új faj, Lautoconus harzhauseri Kovács nov. sp. is leírásra került.

Tárgyszavak: Gastropoda, Paratethys, kainozoos, lutetiai, egri, badeni

\begin{abstract}
In this paper 26 recently collected Cenozoic marine gastropod species from Hungary are briefly described. Two Lutetian (Eocene), two Egerian (Oligocene) and 22 Badenian (Miocene) species are represented; most of them are newlyrecorded, while others are illustrated for the first time as being present in Hungary. The extended stratigraphic and palaeogeographic ranges of the respective species are summarized and a new taxon is introduced: Lautoconus harzhauseri Kovács nov. sp.
\end{abstract}

Keywords: Gastropoda, Paratethys, Cenozoic, Lutetian, Egerian, Badenian

\section{Introduction}

The aim of this paper is to describe and illustrate 26 Cenozoic gastropod species from the Transdanubian and the North Hungarian Mountain Ranges, Hungary. Most of the taxa were hitherto unrecorded from Hungary or only mentioned in faunal lists in the Hungarian literature. The studied materials were collected in the last ten years as a result of new field works at well-known palaeontological sites (Figure 1), and most of them belong to private collections. Amateur fossil collectors have traditionally contributed to palaeontological researches by discovering new fossiliferous localities, donating materials to museums or publishing new data. We hope that our new records may also help to understand better the palaeobiogeographical range of the studied species and the diversity of the Cenozoic mollusc faunas of the Western Tethys and the Paratethys.

\section{Geological setting}

The litho- and biostratigraphy of the Eocene epicontinental formations of the Hungarian Palaeogene Basin were summarized by KeCSKEMÉTI (1998), the Middle Eocene deposits of the Vértes Mts were thoroughly discussed by BUDAI \& FODOR (2008). The fossiliferous beds of the Gánt Depression with grey silty clay or marl and thin coaly clay intercalations represent the upper part of the late Lutetian early Bartonian Forna Formation. Mollusc assemblages from the vicinity were described e.g. by SzÓTs (1953), STRAusz (1962), MihÁLy \& VincZe (1984), and Dell’Angelo et al. (2015). A new locality was exposed by us, it is located on the Szőlő-hegy of Gánt, close to the "Gánti-szőlook" roadcut mentioned by SzŐTs (1953). It is composed of brown clay or clayey sand facies of $1 \mathrm{~m}$ thickness, and yielded one of the Eopustularia specimens figured herein. The Middle Eocene palaeogeography and the lithological formations of the 


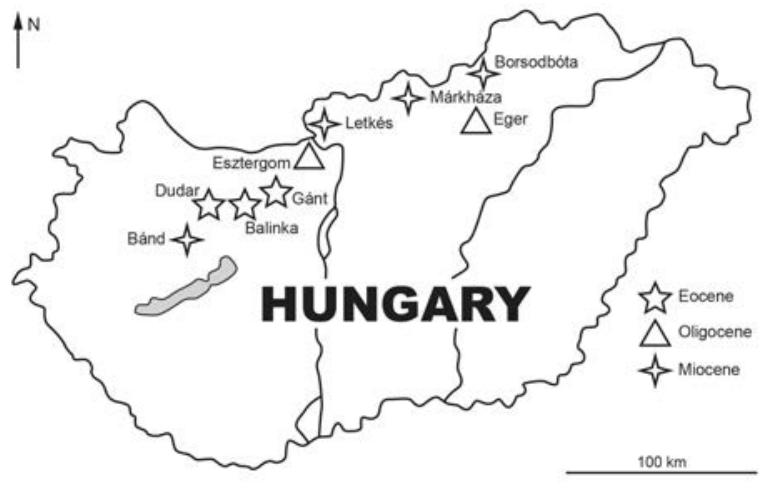

Figure 1. Locations of the studied Hungarian Eocene, Oligocene, and Miocene localities

1. ábra. A szövegben emlitett magyarországi eocén, oligocén és miocén lelöhelyek

Dudar-Jásd and the Balinka Basins (NE Bakony Mts) was treated e.g. by SzôTS (1956), BÁLDI-BEKE \& BÁLDI (1990) and BÁLDI-BEKE (2003). The diverse Lutetian deposits of Dudar and Balinka known from boreholes and coal mines were discussed by KNAUER \& KOPEK (1982) and BERNHARDT (1985), respectively. The clayey sand with brown coal strings, the nummulitic sandstone and the grey marl or siltstone represent the Csernye Formation and have yielded very rich invertebrate assemblages. Mollusc faunas from Dudar were described by STRAUSZ (1966a, 1969), and from Balinka by KECSKEMÉTI-KÖRMENDY (1980). Molluscs can be collected nowadays in the abandoned mine dumps of the villages (OzSVÁRT 2007).

The Late Oligocene (Egerian) stratigraphy and lithological formations of the Eger Brickyard were thoroughly analysed by BÁLDI (1973) and of the Esztergom Basin by SZTANÓ et al. (1998). The diverse Egerian mollusc assemblages from Hungary were described by BÁLDI (1973). The locality of Esztergom-Szentgyörgymező and its gastropod fauna were dealt with by KovÁCS \& VICIÁN (2016), the clayey siltstone deposits belong to the lower member of the Törökbálint Formation.

The Middle Miocene palaeogeography and lithological formations of the Neogene Pannonian Basin were summarized by HÁMOR (2001). All Lower Badenian rocks from the North Hungarian Mountains mentioned in this paper represent the Sámsonháza Formation. Fossiliferous localities of Borsodbóta (Western Bükk Mts) are characterized by a tuffaceous sandy facies. The site with the mollusc fauna were described by CSEPREGHY-MEZNERICS (1969, 1970), while the rich bryozoan fauna and the palaeoenvironment were studied by MoISSETTE et al. (2007). Around Márkháza (East Cserhát Mts) the fossiliferous beds are characterized by clay, clayey sand and tuffaceous sandstone, limestone and andesite conglomerate. The site was mentioned by NOSZKY (1940), later discussed in detail by HEGEDÚs \& JANKOVICH (1972), the mollusc fauna was described by CSEPREGHYMEZNERICs (1954). Deposits of Letkés (Western Börzsöny Mts) consist of limonitic clayey sand with andesite rock fragments and andesitic tuff. The mollusc fauna shows exceptional high diversity among the Hungarian as- semblages (CSEPREGHY-MEZNERICS 1956, KovÁCS \& Vicián 2014, HARZHAUSER \& LANDAU 2016, HARZHAUSER et al. 2017). Near Bánd (Bakony Mts, Transdanubian Range) Lower Badenian clayey sand facies yielded rich marine invertebrate assemblages consisting of numerous coral, gastropod, bivalve, scaphopod, polyplacophoran, brachiopod, scleractinian, cirripedian, echinoid, calcareous algae, bryozoan, decapod and fish taxa (KóKAY 1966, JAKUS 1980, Dulai 2005, 2007). From the Lower Badenian of Márkháza, Borsodbóta and Bánd new Cypraeidae, Pediculariidae and Triviidae species were described by FEHSE \& VICIÁN (2004, 2006, 2008).

\section{Systematic Palaeontology}

Family Strombidae RAFINESQUE, 1815

Genus Europrotomus KronENBERG et HARZHAUSER, 2012

\section{Europrotomus schroeckingeri (HÖRNES in HOERNES \& AUINGER 1884) (Plate 1, figs 1-2)}

1884 Strombus (Monodactylus) Schroeckingeri M. HoERN. HOERNES \& AUINGER, p. 165, pl. 19, figs 6-7.

2012 Europrotomus schroeckingeri (HÖRNES in HOERNES \& AUINGER) comb. nov. - KRONENBERG \& HARZHAUSER, p. 151, figs 2-3 (cum syn.).

Remarks: The species is known from the Lower Badenian of North Hungary (Sámsonháza, Márkháza, Mátraverebély: Cserhát Mts), but only a fragmentary specimen was represented (STRAUSz 1966b, fig. 104). As the type species of the genus is significant from palaeobiogeographical point of view, a well-preserved specimen from Márkháza is figured here.

Distribution: Badenian: Central Paratethys (Styrian Basin: Austria; Făget Basin: Romania; Pannonian Basin: Bosnia and Herzegovina, Hungary; Forecarpathian Basin: NW Bulgaria).

Family Xenophoridae Troschel, 1852

Genus Xenophora FISCHER VON WALDHEIM, 1807

\section{Xenophora italica (GRATELOUP, 1845)}

(Plate 1, figs 3-4)

1845 Trochus conchyliophorus var. Italica - GRATELOUP, pl. 13, fig. 2.

2013 Xenophora italica (GRATELOUP) — LANDAU et al., p. 99, fig. 19/1, pl. 10, figs 1-3, pl. 62, fig. 3 (cum syn.).

Remarks: Two xenophorids are known from the Lower Badenian of Hungary, X. deshayesi (MichelotTI) (Mecsek and Cserhát Mts, STRAUSz 1966b) and Stellaria testigera (BronN) (Bükk Mts, Csepreghy-Meznerics 1969). The specimen from Letkés represents a third taxon, $X$. italica. It differs from $X$. deshayesi in straight sided whorls with finer sculpture, and showing a preference for agglutinating smaller pebbles, bivalve fragments and small gastropod 
shells. The specimen bears several Amalda glandiformis (LAMARCK) and a Projenneria albopunctata FEHSE et VICIÁN shells.

Distribution: Langhian: NE Atlantic (Aquitaine Basin: France), Badenian: Central Paratethys (Pannonian Basin: Hungary), Serravallian: Proto-Mediterranean Sea (Karaman Basin: Turkey).

Family Cypraeidae RAFINESQUE, 1815

Genus Eopustularia FeHSE, 2010

\section{Eopustularia balinka FEHSE, 2010} (Plate 1, figs 5-9)

2010 Eopustularia balinka n. sp. - FEHSE, p. 6, pl. 5, figs 1-5. 2014 Eopustularia balinka FEHSE — LORENZ, p. 11, text-fig. 2/3.

Remarks: This recently described species (type of the genus) is a rare element of the Lutetian mollusc faunas of Italy, but is abundant at Balinka (Hungary). Two other Eopustularia species are known from Hungary: E. moloni (BAYAN) differs in finer teeth, shorter terminals, and rounded sides and dorsal profile, while E. gregorioi (SCHILDER) has a larger shell with less keeled sides and less margined anterior extremity. As all types of E. balinka are deformed specimens, we represent here a well-preserved specimen from Gánt (Szőlő-hegy), and another from Balinka. (Note: the type locality of the species is Balinka in Hungary. Fejér is the name of the county where village Balinka is located.)

Distribution: Lutetian: W Tethys (Hungarian Palaeogene Basin), Bartonian: W Tethys (N Italian Basin).

Genus Propustularia ScHILDER, 1927

\section{Propustularia neugeboreni \\ (HOERNES et AUINGER, 1880) (Plate 1, figs 10-12)}

1880 Cypraea (e. Aricia) Neugeboreni nov. form. - HoERnES \& AUINGER, p. 60, pl. 7, figs 5-6, pl. 8, fig. 6.

1998 Propustularia neugeboreni neugeboreni (HOERNES et AUINGER) — Dolin, p. 107 (pars), fig. 9.

Remarks: The species differs from other Miocene cypraeids in a unique morphological feature: the teeth are very long, they reach the margins on both sides. P. neugeboreni is a new record from Hungary. It rarely occurs in the Lower Badenian deposits of North Hungary (Márkháza, Sámsonháza, Borsodbóta), but is unknown from the highly diverse cypraeid assemblage of Letkés. The western boundary of its range is probably the Cserhát Mts region in the Central Paratethys.

Distribution: Badenian: Central Paratethys (Făget and Hațeg Basins: Romania; Pannonian Basin: Bosnia and Herzegovina, Hungary; Forecarpathian Basin: NW Bulgaria).
Family Cassidae LATREILLE, 1825

Genus Cassis ScOPOLI, 1777

\section{Cassis postmamillaris SACCO, 1890}

Plate 1, figs 13-14)

1890 Cassis postmamillaris SACCO - SACCO, p. 16, pl. 1, fig. 11. 2013 Cassis postmamillaris SACCO — LANDAU et al., p. 123, pl.

17, figs 2-4, pl. 79, fig. 8 (cum syn.).

Remarks: The species was recorded from Hungary as $C$. mamillaris GRATELOUP without illustration by NOSZKY (1925, 1940) (N Börzsöny Mts, E Cserhát Mts). C. postmamillaris is abundant in the early Badenian mollusc assemblages of Letkés and Sámsonháza. (The highly diverse Tonnoidea fauna of Letkés is described by KovÁCS \& VICIÁN in press.)

Distribution: Langhian: Proto-Mediterranean Sea (Torino Hills: Italy), Badenian: Central Paratethys (Vienna Basin: Austria, Czech Republic, Slovakia; Pannonian Basin: Hungary; Făget Basin: Romania), Serravallian: Proto-Mediterranean Sea (Mezohellenic Basin: Greece; Karaman Basin: Turkey). Tortonian: Proto-Mediterranean Sea (Po Basin: Italy).

Family Epitoniidae BERRY, 1910

Genus Sthenorytis CONRAD, 1862

\section{Sthenorytis cf. pseudoretusa (Sacco, 1891)}

(Plate 1, figs 15-16)

1891 Cirsotrema? pseudoretusum SACC. - SACCO, p. 43, pl. 2, fig. 7.

1912 Sthenorytis pseudoretusa SACCO - DE BOURY, p. 233, pl. 12, figs 7-8.

1984 Cirsotrema? pseudoretusum SACCO - FERRERo MorTARA et al., p. 46, pl. 5, fig. 9a, b.

Remarks: Only a single epitoniid was recorded from the Upper Oligocene of Hungary (NOSZKY 1936), a Scalaria rusticum cf. transiens SACCO, but the specimen was destroyed by fire during the Hungarian Uprising of 1956. Our fragmentary specimen (donation of Tamás NÉMETH) was collected ex situ at the Egerian locality of EsztergomSzentgyörgymezô. It corresponds to the type of $S$. pseudoretusa in overall morphology (turbinate shell, rounded whorls, thick, spined axial ribs, rounded aperture). The type, however, bears 15 axial ribs on the last whorl, while our specimen has only 13 ribs, and is ornamented with fine spiral cords. The sculpture is similar to that of the Middle Oligocene $S$. subpyrenaica TOURNOUËR, but the latter is characterized by somewhat finer ribs with varices. $S$. subpyrenaica depexa (ROVERETO) differs by the lack of spines.

Distribution: Early Oligocene: W Tethys (N Italy), Egerian: Paratethys (Hungary). 
Family Harpidae BRONN, 1849

Genus Morum RöDING, 1798

Morum cythara (Brocchi, 1814)

(Plate 1, fig. 17)

1814 Buccinum cythara - BROCCHI, p. 330, pl. 5, fig. 5.

1966b Morum (Oniscidia) cithara BROCCHI - StRAUSZ, p. 242, pl. 64 , figs $8-9$.

2016 Morum cythara (BROCCHI) - STEIN et al., p. 101, pl. 46, figs 1-2 (cum syn.).

Remarks: The species is abundant in Badenian localities of Hungary, but has never been recorded from Egerian deposits. The strong nodulose sculpture of the specimen is close to the forms described by SACCO (1890) from the Italian Oligocene. M. dunkeri SPEYER from the Chattian of the North Sea Basin is similar in sculpture, but differs in lower spire and in broad and flat spiral cords. Two M. cythara specimens are recorded herein from the Eger Brickyard.

Distribution: Oligocene: N Tethys (Italy), Egerian: Paratethys (Hungary), Aquitanian-Langhian: NE Atlantic (Aquitaine Basin: France), Burdigalian: Proto-Mediterranean Sea (Italy), late Burdigalian - Langhian: North Sea Basin (the Netherlands), Serravallian-Tortonian: NE Atlantic (Portugal), Badenian: Paratethys (Vienna Basin: Austria, Korytnica Basin: Poland, Pannonian Basin: Bosnia, Hungary; Transylvanian Basin: Romania; Forecarpathian Basin: Ukraine, NW Bulgaria), Serravallian: Proto-Mediterranean Sea (Karaman Basin: Turkey), Tortonian: ProtoMediterranean Sea (Po Basin, Italy).

Family Muricidae RAFINESQUE, 1815

Genus Pterynotus SwaINSON, 1833

\section{Pterynotus granuliferus (GRATELOUP, 1833)} (Plate 2, figs 1-2)

1833 Murex granuliferus Nob. - GRATELouP, p. 96.

2013 Pterynotus granuliferus (GRATELOUP) - LANDAU et al., p. 148, pl. 21, figs 12-13 (cum syn.).

Remarks: As with the rich early Badenian Conidae fauna of Letkés (see KovÁcs \& Vicián 2013, HARZHAUSER \& LANDAU 2016), the family Muricidae also shows a much higher diversity than previously recognized. Seven hitherto unrecorded muricids are described herein from the locality. Pterynotus granuliferus is a new record from Hungary, it was a rare element of the mollusc assemblage.

Distribution: Burdigalian-Langhian: NE Atlantic (Aquitaine Basin: France), Badenian: Central Paratethys (Vienna Basin: Austria; Făget Basin: Romania; Korytnica Basin: Poland; Pannonian Basin: Hungary; Forecarpathian Basin: NW Bulgaria), Serravallian: Proto-Mediterranean Sea (Karaman Basin: Turkey), Tortonian: Proto-Mediterranean Sea (Po Basin: Italy).
Genus Purpurellus JoussEAume, 1880

Purpurellus cyclopterus (MILLET, 1865)

(Plate 2, figs 3-4)

1865 Murex cyclopterus - MiLLET, p. 592.

2016 Purpurellus cyclopterus (MILLET) - LANDAU et al., p. 224, pl. 1, fig. 3 (cum syn.).

Remarks: P. cyclopterus has an unusually long stratigraphical and a wide palaeogeographical range, however, it is very rare in the Badenian gastropod faunas of the Paratethys. The specimen figured here came from Letkés.

Distribution: Early-Middle Miocene: NE Atlantic (Aquitaine Basin, Loire Basin: France), Langhian-Serravallian: Proto-Mediterranean Sea (Torino Hills: Italy; Karaman Basin: Turkey), Badenian: Central Paratethys (Făget Basin: Romania; Korytnica Basin: Poland; Pannonian Basin: Hungary), Tortonian: NE Atlantic (France, Portugal), Proto-Mediterranean Sea (Italy). (For Pliocene range see LANDAU et al. 2016)

Genus Dermomurex Monterosato, 1890

Subgenus Dermomurex s.s.

\section{Dermomurex (s.s.) distinctus \\ (CRISTOFORI et JAN, 1832) \\ (Plate 2, figs 5-8)}

1832 Murex distinctus - CRISTOFORI \& JAN, p. 11.

2011 Dermomurex (s.s.) distinctus (CRISTOFORI et JAN) - MERLE et al., p. 215, text-fig. 72/F, pl. 166, figs 1-8.

Remarks: Dermomurex distinctus is a new record for the Hungarian assemblages, it is a rare element of the mollusc faunas of Letkés and Bánd. D. scalaroides (BLAINVILLE) is similar in size and morphology, but differs in more slender shell with higher spire, and finer sculpture.

Distribution: Middle Miocene: NE Atlantic (Loire Basin: France), Badenian: Central Paratethys (Vienna Basin: Austria; Korytnica Basin: Poland; Pannonian Basin: Hungary), Late Miocene - Pliocene: Proto-Mediterranean Sea (Italy).

Genus Favartia Jousseaume, 1880

Subgenus Pygmaepterys VOKES, 1978

\section{Favartia (Pygmaepterys) transsylvanica}

(Hoernes et Auinger, 1885)

(Figure 2, Plate 2, figs 9-10)

1885 Murex (Muricidea) transsylvanicus nov. form. - HOERNES \& AUINGER, p. 207, pl. 24, fig. 12.

1906 Murex (Muricidea) transsylvanicus HoERNES et AUINGER BOETTGER, p. 44.

Remarks: As it is the first appearance of P. transsylvanica outside of the type locality (Lăpugiu de Sus, Coşteiu 
de Sus), a revised description is provided here: Small shell (SL max. $14 \mathrm{~mm}$ ), protoconch of 1.75 smooth, rounded whorls, teleoconch of five rounded whorls. Last whorl 57$60 \%$ of total length of teleoconch, ovate aperture, six denticles within the outer lip (ID, D1-D5), columellar lip weakly plicate with six fine, narrow plications, siphonal canal (26\% of total length of teleoconch) open and slightly dorsally recurved. Scabrous shell surface, spiral sculpture of strong primary cords (P) (first whorl: appearance of P1, P2 and infrasutural primary cord [IP]; last whorl: adapical secondary cord (adis) and weakly developed IP on ramp, strong P1-P4, weakly developed P5-P6 and adapical [ADP], median [MP] and abapical [ABP] primary cords). Axial sculpture of seven slightly lamellose varices since the first whorl, small spinelets on varices (Figure 2). The specimens figured here agree with the type, and with specimens from Coşteiu (collection of the Hungarian Natural History Museum) in overall morphology, but due to better state of preservation their sculpture are much stronger. The species shows intraspecific variability in number of varices. We searched 26 specimens from which two bear eight varices and two bear only six.

The genus level arrangement is ambiguous in the literature. The species was cited as Dermomurex by VOKES (1971) and STOJASPAL (1978) without any description, but it was not mentioned by MerLe et al. (2011) among Dermomurex taxa. Based on morphological characteristics (small shell with seven winged varices, strong spiral sculpture, crenulate axial growth lamellae, denticulate aperture) we assign the species to subgenus Pygmaepterys (see VOKES 1978, 1994). Two other Pygmaepterys species are known from the Early - Middle Miocene of Europe: $F$. (P.) subdecussata (D'ORBIGNY) and $F$. (P.) giselae (BOETTGER). The first has a more slender shell with weaker spiral sculpture and bears well-developed denticles within the inner lip (VOKES 1994, pl. 25, fig. 3), while the second differs in wider shell with lower spire, and longer spinelets (ZILCH 1934, pl. 15 , fig. 79). P. transsylvanica is common in the mollusc assemblage of Bánd.

Distribution: Badenian: Central Paratethys (Făget Basin: Romania; Pannonian Basin: Hungary).

Genus Ocinebrina Jousseaume, 1880

\section{Ocinebrina kojumdgievae (BAŁUK, 1995)} (Plate 2, figs 11-12)

1995 Purpura (Tritonalia) kojumdgievae nom. n. - BAŁUK, p. 228, pl. 30, fig. 8 .

2013 Ocinebrina kojumdgievae (BAŁUK) - GorET \& PONS, p. 60, pl. 3, fig. 3 (cum syn.).

Remarks: The morphological differences between $O$. lassaignei (BASTEROT) and O. kojumdgievae, as well as the close morphological and evolutionary relationship between the middle Miocene $O$. kojumdgievae, the late Miocene $O$. saccoi (Cossmann et PeYrot), and the Pliocene O. ariesi-

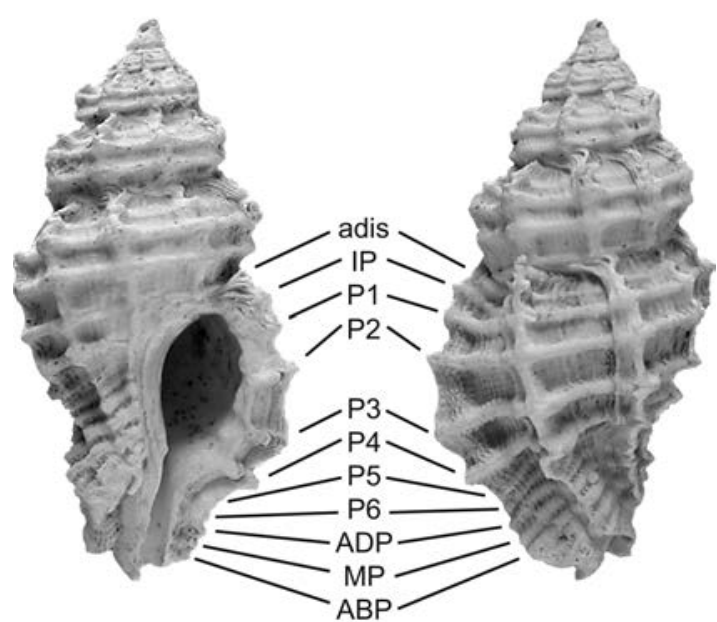

Figure 2. Favartia (Pygmaepterys) transsylvanica (HoERNES et AUINGER), shell length $14 \mathrm{~mm}(4 \times)$, Bánd, collection Zoltán Vicián

2. ábra. Favartia (Pygmaepterys) transsylvanica (HOERNES et AUINGER), ház hossza: $14 \mathrm{~mm}(4 \times)$, Bánd, Vicián Zoltán gyüjteménye

nensis (FONTANNES) were discussed in detail by LANDAU et al. (2007). The species is a new record from Hungary, it rarely occurs in the Lower Badenian deposits of Márkháza.

Distribution: Miocene: W Paratethys (Hérault Basin: France), Badenian: Central Paratethys (Vienna Basin: Austria; Korytnica Basin: Poland; Făget Basin: Romania; Pannonian Basin: Hungary; Forecarpathian Basin: NW Bulgaria), Serravallian: Proto-Mediterranean Sea (Karaman Basin: Turkey).

Genus Ceratostoma HerRmannsen, 1846

Ceratostoma subaustriacus (STOJASPAL, 1978)

(Plate 2, figs 13-14)

1853 Murex Genei - HöRNES, p. 231, pl. 24, figs 6-7 (non Murex genei BELLARDI et MichelotTI, 1840).

1885 Murex austriacus - HoERnes \& AUINGER, p. 194 (new name for Murex Genei in HöRNES, 1853).

1978 Jaton (Ceratostoma) subaustriaca nom. nov. - STOJASPAL, p. 335 (nom. nov. pro austriaca HoERnES et AUINGER 1885).

Remarks: The morphological differences between Murex genei Bellardi et MichelotTI and the specimens figured by HöRNES (1853, pl. 24, figs 6-7) were emphasized by HoERnes \& Auinger (1885), and a new name, Murex austriacus was proposed for the specimens of the Vienna Basin. This name is an objective homonym of Murex austriacus TOURNOUËR, 1875, and must be replaced according to the ICZN, although VOKES (1971) placed the species within genus Ceratostoma, while TOURNOUËR's taxon belongs to genus Hexaplex (Trunculariopsis) (MERLE et al. 2011). STOJASPAL (1978) introduced a new name in a list indicating "pro austriaca HöRNES et AUINGER, 1885". Although this arrangement is not very satisfying as STOJASPal did not discuss any details, the name is available, and is used herein. 
As all Jaton species differ from Ceratostoma species in strongly shouldered whorls (LANDAU et al. 2007), we assign subaustriacus to Ceratostoma that was treated in genus level within the Ocenebrinae by VermeIJ \& VoKes (1997). The shell morphology of $C$. subaustriacus agrees with the diagnosis of the latter authors, the labral tooth is present; however, the specific cancellate sculpture of the early whorls, due to poor state of preservation, cannot be traced.

Distribution: Badenian: Central Paratethys (Vienna Basin: Austria; Pannonian Basin: Hungary).

Genus Murexsul IREDALE, 1915

\section{Murexsul sandbergeri (HÖRNES, 1856)}

(Plate 2, figs 15-16)

1856 Murex Sandbergeri HÖRN. - HÖRNES, p. 674, pl. 51, fig. 5. 2013 Murexsul sandbergeri (HöRNES) — LANDAU et al., p. 160, pl. 24, figs 3-4 (cum syn.).

Remarks: The species is widely distributed in the Paratethys, but is a rare element of the mollusc assemblages. Our specimen is the first record from Hungary, it came from Letkés.

Distribution: Badenian: Central Paratethys (Vienna Basin: Austria; Korytnica Basin: Poland; Făget Basin: Romania; Pannonian Basin: Hungary), Serravallian: ProtoMediterranean Sea (Karaman Basin: Turkey).

Genus Subpterynotus OLSSON et HARBISON, 1953

\section{Subpterynotus graniferus (MichelOTTI, 1841)} (Plate 2, figs 17-18)

1841 Murex graniferus mihi - Michelotti, p. 11, pl. 5, fig. 6 . 2013 Subpterynotus graniferus (MicheLOTTI) — LANDAU et al., p. 162, pl. 24, figs 6-7 (cum syn.).

Remarks: The species is abundant in Miocene localities of Europe, however, it has not yet been recorded from Hungary. Our specimen came from Letkés.

Distribution: Aquitanian-Burdigalian: NE Atlantic (Aquitaine Basin: France), Burdigalian: Proto-Mediterranean Sea (Torino Hills: Italy), Badenian: Central Paratethys (Vienna Basin: Austria, Czech Republic; Făget Basin: Romania; Pannonian Basin: Hungary), Serravallian: ProtoMediterranean Sea (Karaman Basin: Turkey), Tortonian: Proto-Mediterranean Sea (Po Basin: Italy).

Genus Tripterotyphis PILSBRY et Lowe, 1932

Tripterotyphis wenzelidesi (HöRNES, 1853)

(Plate 2, fig. 19)

1853 Murex (Typhis) Wenzelidesi HöRnES - HöRnES, p. 264, pl. 26, fig. 12

1978 Typhis wenzelidesi (HoERnES) - StOJASPAL, p. 335.
Remarks: The shell morphology of $T$. wenzelidesi and $T$. tripterus (GRATELOUP) is closely affiliated and the two taxa were frequently considered as conspecific. We do not know any modern revision or comparison of the types, so provisionally accept the validity of both taxa, and treat wenzelidesi as a species typical of the Badenian of the Central Paratethys. It is a new record from Hungary.

Distribution: Badenian: Central Paratethys (Vienna Basin: Austria; Făget Basin: Romania; Pannonian Basin: Hungary).

Genus Coralliophila H. AdAms et A. AdAms, 1853

\section{Coralliophila gracilispira BOETTGER, 1906}

(Plate 2, figs 20-21)

1906 Coralliophila gracilispira n. sp. - BOETTGER, p. 35 .

1934 Coralliophila gracilispira BOETTGER - ZILCH, p. 252, pl. 15, fig. 82.

1995 Coralliophila (Coralliophila) gracilispira BOETTGER BAŁUK, p. 230, pl. 27, figs 7-9.

Remarks: A brief revision of the species was rendered by BAŁUK (1995). According to the author the C. alternata (BEllardi) specimen in HoERnEs \& AUINGER (1885, pl. 27, fig. 8) can be attributed to $C$. gracilispira. In our opinion BOETTGER's taxon differs from alternata by a more elongated shell. The species is a new record from Márkháza and Letkés.

Distribution: Badenian: Central Paratethys (Făget Basin: Romania; Korytnica Basin: Poland; Pannonian Basin: Hungary).

Family Buccinidae RAFINESQUE, 1815

Genus Aplus DE GREGORIO, 1885

\section{Aplus varians (MichelOTTI, 1847)} (Plate 3, figs 1-3)

1847 Triton varians - MichelotTI, p. 250, pl. 16, fig. 10.

1872 Pollia varians (MichelotTI) - Bellard, p. 180, pl. 12, fig. 19.

1872 Pollia angusta Bellardi - Bellardi, p. 181, pl. 12, fig. 20. 1904 Tritonidea varians (MICHELOTTI) var. productocostata SACCO —SACCO, p. 59, pl. 14, figs 69, 70.

Remarks: The axial sculpture variability of the species was emphasized by BELLARDI (1872), HILBER (1879) and HOERNES \& AUINGER (1890), and it is confirmed by our material of 22 specimens. Adults can bear three varices on teleoconch whorls (Pl. 3, fig. 1), two varices on the last whorl (Pl. 3, fig. 2) or only the labral varix (Pl. 3, fig. 3). The number of varices can be interpreted as more or less advanced growth stages, otherwise the specimens share identical morphology. Based on a revised generic diagnosis (AISSAOUI et al. 2016) the species is assigned to genus Aplus herein. Pollia angusta was already regarded as a synonym by HOERNES \& AUINGER (1890), this arrangement is accepted here. Pollia philippii MichelotTI and Philbertia 
hungarica CSEPREGHI-MEZNERICS are also very similar forms. The holotype of hungarica (HNHM M.61.4369) agrees well in morphology with $A$. varians; however, we do not know any modern discussion of philippii. In lack of comparisons of types it is not possible to determine the validities but new investigations might demonstrate that the four taxa are conspecific. The species occurs at Bánd, Letkés, Márkháza and Borsodbóta in Hungary.

Distribution: Burdigalian-?Langhian: Proto-Mediterranean Sea (Torino Hills: Italy), Badenian: Central Paratethys (Vienna Basin, Styrian Basin: Austria; Făget Basin: Romania; Pannonian Basin: Hungary).

Genus Metula H. AdAms et A. AdAMs, 1850

\section{Metula submitraeformis (D'ORBIGNY, 1852)} (Plate 3, figs 4-5)

1845 Fusus mitraeformis GRAT. — GRATELOUP, pl. 24, figs 36-38, pl. 46, fig. 25 (non mitraeformis BROCCHI).

1852 Fusus submitraeformis D'ORB. - D'ORBIGNY, p. 66 (new name for Fusus mitraeformis GRATELOUP).

2013 Metula submitraeformis (D'ORBIGNY) - LANDAU et al., p. 167, pl. 53, fig. 17, pl. 79, fig. 11 (cum syn.).

Remarks: Metula submitraeformis is widely distributed in Burdigalian-Langhian deposits from the North Sea Basin, southwards along the western Atlantic frontage, the Paratethys and the Proto-Mediterranean Sea. The species differs from the similar M. mitraeformis (BROCCHI) from the Italian Pliocene in multispiral protoconch and reticulated early teleoconch whorls. The species is a new record from Hungary.

Distribution: Burdigalian: Molasse Basin (Germany), late Burdigalian - Langhian: North Sea Basin (the Netherlands), Langhian: North Sea Basin (Germany), NE Atlantic (Aquitaine Basin: France), Badenian: Central Paratethys (Vienna Basin: Austria; Pannonian Basin: Hungary; Romania), Serravallian: Proto-Mediterranean Sea (Karaman Basin: Turkey).

Family Colubrariidae DALL, 1904

Genus Colubraria SCHUMACHER, 1817

\section{Colubraria subobscura (HoERnEs ET AuINGER, 1884) (Plate 3, figs 6-9)}

1884 Triton (Epidromus) subobscurum nov. form - HOERNES \& AUINGER, p. 181, pl. 22, figs 4-7.

1960 Colubraria (Colubraria) subobscura (HoERnes et AUINGER) — Kojumdgieva, p. 139, pl. 38, fig. 3.

Remarks: The rare species is typical of the Central Paratethys. It is a new record from Letkés, Hungary.

Distribution: Badenian: Central Paratethys (Vienna Basin: Austria; Făget Basin: Romania; Pannonian Basin: Hungary; Forecarpathian Basin: NW Bulgaria).
Family Cancellariidae Forbes et HANLEy, 1851

Genus Scalptia Jousseaume, 1887

\section{Scalptia neugeboreni (Hörnes, 1856)}

(Plate 3, fig. 10)

1856 Cancellaria Neugeboreni - HÖRNES, p. 680, pl. 52, fig. 6. 2012 Scalptia neugeboreni (HÖRNES) - HARZHAUSER \& LANDAU, p. 46, fig. 9C (cum syn.).

Remarks: The presence of this extremely rare species in the Letkés assemblage is remarkable. Both Scalptia leopoldinae (TOURNOUËR) and S. polonica (PUSCH) are similar in morphology, but the first differs from neugeboreni in wider and deeper sutures and nearly closed umbilicus, while the second lacks a fold on the parietal part of the aperture and bears much stronger secondary spiral sculpture.

Distribution: Badenian: Central Paratethys (Vienna Basin: Czech Republic, Austria; Făget Basin: Romania; Pannonian Basin: Hungary).

Family Conidae FLEMING, 1822

Genus Eoconus TuCKer et TENORIO, 2009

\section{Eoconus cf. conotruncus (DE GREGORIO, 1880)}

\section{(Plate 3, figs 11-12)}

1880 Conus (Conus) conotruncus DE GREG. - DE GREGORIO, p. 70, pl. 5, figs 3-4.

non 1970 Conus conotruncus DE GREGORIO - FERRERO \& PICCOLI, p. 7, pl. 1, fig. 2. (= Eoconus latissimus KocH in MészÁros, 1957).

Remarks: Two Eoconus species are frequent in the Eocene localities of Hungary, E. deperditus (HwAss in Bruguière) and E. diversiformis (DESHAYES). The first is characterized by relatively higher, the second by lower spire (STRAUSz 1966a). Our specimen from the Lutetian of Dudar with shorter body whorl, flat spire and channeled spiral whorls represents a third taxon. Three Eoconus species are known from the Middle Eocene of the Western Tethys with depressed to flat spire, E. planus (SCHAUROTH), E. latissimus (KoCH in MÉSZÁrOS) and E. conotruncus (DE GREGORIO). The first two differ by extremely broad shell, the closest form is the last one. Its type has a slender shell, and a depressed, almost flat spire with channeled and striate spiral whorls. Although our specimen is a moderately deformed internal mold, its shell proportion agrees with that of the type. However, the height of the early spiral whorls and the spiral striae of the late spiral whorls cannot be traced, so the specimen is referred here in open nomenclature. A poorly preserved Conus sp. with similar morphology was recorded by KECSKEMÉTI-KÖRMENDY \& MÉSZÁROS (1980, p. 107, pl. 13, fig. 13) from the Eastern Bakony Mts, but it requires further research.

Distribution: Lutetian: W Tethys (N Italian Basin, Hungarian Palaeogene Basin). 
Genus Lautoconus MonTEROSATO, 1923

\section{Lautoconus oboesus (MichelOTTI, 1847)}

(Plate 3, figs 13-14)

1847 Conus oboesus - MichelotTI, p. 342.

1893 Chelyconus oboesus (MicheLOTTI) - SACCO, p. 58, pl. 5, fig. 31.

1966 Conus oboesus MichelotTI - HALL, p. 153, pl. 26, figs 1718.

Remarks: The species was mentioned from Letkés as a new record by Kovács \& BALÁzs (2016). The shell morphology of the specimen figured here (spire of 8 subangulate whorls with straight outline, a faint spiral groove on shoulder, slightly convex and smooth body whorl with fine grooves at base, moderately deep growth lines, narrow aperture, asymmetrically curved subsutural flexure) is very close to that of L. oboesus from the Middle Miocene of Northern Italy. L. pelagicus (BROCCHI) differs in welldeveloped siphonal fasciole, L. ? vindobonensis (HOERNES et AUINGER) bears beaded early and striate late spiral whorls, while Plagioconus puschi (MichelOTTI) has longer body whorl and shallower, diagonal flexure.

Distribution: Langhian: Proto-Mediterranean Sea (Torino Hills: Italy), Badenian: Central Paratethys (Pannonian Basin: Hungary).

\section{Lautoconus? praelongus \\ (Hoernes et Auinger, 1879)}

(Plate 3, figs 15-16)

1879 Conus (Chelyconus) praelongus nov. form. - HOERNES \& AUINGER, p. 45, pl. 1, fig. 16.

2016 Varioconus praelongus (HOERnES et AUINGER) - KOVÁCS \& BALÁzs, p. 33, figs 77-78 (cum syn.).

2016 Conus s.l. praelongus HoERnES \& AUINGER - HARZHAUSER \& LANDAU, p. 146, figs 30L, 34B-D (cum syn.).

Remarks: This rare species was also recorded from Letkés by KovÁcs \& BALÁzs (2016). Its shell morphology was thoroughly revised by HARZHAUSER \& LANDAU (2016), however, the genus level classification remained open.

Distribution: Badenian: Central Paratethys (Făget Basin: Romania; Eisenstadt-Sopron Basin: Austria; Pannonian Basin: Hungary; Forecarpathian Basin: NW Bulgaria).

\section{Lautoconus harzhauseri KovÁCS nov. sp. (Plate 3, figs 17-21)}

2014 Monteiroconus mercati - KovÁcs \& VICIÁN, figs 87-88 only [non Monteiroconus mercati (BROCCHI)].

2016 Lautoconus nov. sp. [ex. gr. bitorosus Fontannes] HARZHAUSER \& LANDAU, p. 97, figs 17G, 22A.

Holotype: PAL 2017.49, Hungarian Natural History Museum, Department of Palaeontology and Geology, (SL 48, MD 28) (Plate 3, figs 17-18, refigured from KovÁcs \& ViCiÁn 2014, figs 87-88).
Paratypes: $1^{\text {st: }}$ PAL 2017.50 (SL 53, MD 30) (Plate 3, figs 19-20), $2^{\text {nd. }}$ PAL 2017.51 (SL 41, MD 23), $3^{\text {rd: }}$ PAL 2017.52.

Type strata: Lower Badenian (Middle Miocene) clayey sand (Sámsonháza Formation).

Type locality: Letkés, W Börzsöny Mts, Hungary.

Derivation of name: In honour of Mathias HARZHAUSER palaeontologist (Naturhistorisches Museum Vienna).

Material: five moderately preserved specimens.

Diagnosis: Medium-sized shell, low spire, seven spiral whorls with two striae, smooth, subcylindrical body whorl, narrow aperture, shallow, asymmetrically curved subsutural flexure.

Description: Medium-sized shell. Moderately low spire (spire angle $130-132^{\circ}$ ), outline straight, apex slightly projected. Seven spiral whorls, slightly convex to concave with two faint striae, suture deep, shoulder angulate. Body whorl angle $37-38^{\circ}$, whorl smooth with fine ridges at base, outline subcylindrical with maximum diameter somewhat below the shoulder. Aperture moderately narrow, siphonal fasciole slightly swollen and twisted, siphonal canal broad and short. Subsutural flexure asymmetrically curved, shallow. Colour pattern of the $1^{\text {st }}$ paratype in normal light consists of dense spiral stripes of thin dashes on body whorl, while in UV light last whorl covered by three broad bands at about upper fourth, mid-whorl and lower fourth.

Remarks: In their comprehensive Conidae revision HARZHAUSER \& LANDAU (2016) described and emphasized the specific shell morphology of two specimens from Letkés, but they refrained from introducing a new taxon. Based on newly collected material as well as the revision of the Conidae collection of the Hungarian Natural History Museum a new species is described herein. L. harzhauseri nov. sp. differs from other Miocene conoids in subcylindrical body whorl. The taxon is known only from Letkés, it is a rare element of the mollusc assemblage.

Distribution: Badenian: Central Paratethys (Pannonian Basin: Letkés, Hungary).

Family Clathurellidae H. AdAMs et A. AdAMs, 1858

Genus Clathurella CARPENTER, 1857

\section{Clathurella vasta (BOETTGER, 1906)}

(Plate 3, fig. 22)

1906 Drillia (Crassispira) vasta n. sp. - BOETTGER, p. 57.

1934 Turris (Crassispira) vasta (BOETTGER) - ZILCH, p. 261, pl. 17, fig. 29.

2003 Clathurella vasta (BOETTGER)—BAŁUK, p. 66, pl. 26, fig.3-4.

Remarks: This rare species is characterized by the multitude of densely compressed, fine spirals, and in this regard it has a great similarity to another rare Clathurella species: $C$. casilorica BoETTGER, but $C$. vasta has been separated by its much more compact form. In the case of a larger number of finds, however, it could be possible that the 
two taxa are conspecific. The species is a new record from Hungary, the specimen figured here came from Borsodbóta.

Distribution: Badenian: Central Paratethys (Făget Basin: Romania; Korytnica Basin: Poland; Pannonian Basin: Hungary).

\section{Conclusion}

The gastropod records described in the present paper contribute to the knowledge of the Cenozoic marine mollusc faunas of the W Tethys and the Paratethys. Extended palaeogeographic distribution of 21 relatively rare species in the Central Paratethys [e.g. Xenophora italica (GRATELOUP), Propustularia neugeboreni (HoERnes et AuINGER), Pterynotus granuliferus (GRATELOUP), Favartia (Pygmaepterys) transsylvanica (HOERNES et AUINGER), Ocinebrina kojumdgievae (BAŁUK), Tripterotyphis wenzelidesi (HöRNES), Colubraria subobscura (HoERnEs et AUINGER), Clathurella vasta (BOETTGER)] is demonstrated. The occurrence of $M o$ rum cythara (BROCCHI) in the Egerian proves the long stratigraphic range of the taxon. Cassis postmamillaris SACCO is illustrated for the first time from Hungary. The discussion of Aplus varians (MichelotTI) may help to understand genus Aplus and the related forms. The occurrence of Lautoconus oboesus (MiCHELOTTI) and L.? praelongus (HOERnES et AUINGER) in Hungary, as well as the introduction of Lautoconus harzhauseri Kovács nov. sp. illustrate well the high diversity of the family Conidae in the early Badenian of the Central Paratethys.
Both the new field works and the revisions of private fossil collections presented here give a more detailed picture of the Lutetian, Egerian and Badenian gastropod diversity in Hungarian sites. Mainly the research of the mollusc assemblage from Letkés provides remarkable results. Similarly to the diverse superfamilies Conoidea, Tonnoidea and Ficoidea mentioned above, the Cypraeidea and Muricoidea faunas of the locality are also characterized by an outstanding richness - descriptions of these groups are in progress.

\section{Acknowledgements}

We are indebted to Miklós KÁzMÉr and István SzENTE (Eötvös University, Budapest), Alfréd DulaI (Hungarian Natural History Museum), Alan G. BEU (GNS Science, Lower Hutt, New Zealand), Alain Cluzaud (Pessac, France), Ronald JANSSEN (Senckenberg Forschungsinstitut, Germany), and Felix LORENZ (Germany) for professional help. Constructive reviews by Mathias HARZHAUSER (Naturhistorisches Museum Vienna), Bernard M. LANDAU (Naturalis Biodiversity Center, Leiden), A. DulaI and I. SzENTE helped to improve the manuscript. Gerhard STEIN (Germany) helped our work with photographs. Fossil collectors: Tamás HiRmeTzL, László NÁDAI and Tamás NÉMETH (Hungary) kindly offered their private collections for study. The staff of the Geological Library of the GGIH is also thanked for help.

\section{References - Irodalom}

Aissaoui, Ch., Puillandre, N., Bouchet, Ph., Fassio, G., Modica, M. V. \& Oliverio, M. 2016: Cryptic diversity in Mediterranean gastropods of the genus Aplus (Neogastropoda: Buccinidae). — Scientia Marina 80/4, 521-533. http://doi.org/10.3989/ scimar.04422.12a

BÁLDI, T. 1973: Mollusc fauna of the Hungarian Upper Oligocene (Egerian). — Akadémiai Kiadó, Budapest, 511 p.

BÁLDI-BEKE, M. 2003: Stratigraphy and palaeoecology of the formations overlying the Middle Eocene coal sequence based on nannofossils - (Transdanubia, Hungary). — Földtani Közlöny 133/3, 325-343 (In Hungarian with English abstract).

BÁLDI-BEKE, M. \& BÁLDI, T. 1990: Subsidence history of the Bakony Eocene basin in W-Hungary. — Általános Földtani Szemle 25, 83118. (In Hungarian with English abstract).

BAŁuK, W. 1995: Middle Miocene (Badenian) gastropods from Korytnica, Poland Part II. — Acta Geologica Polonica 45/3-4, 153-255.

BAŁUK, W. 2003: Middle Miocene (Badenian) gastropods from Korytnica, Poland Part IV - Turridae. _ Acta Geologica Polonica 53/1, 29-78.

BELlardi, L. 1872: I Molluschi dei terreni terziari del Piemonte e della Liguria. Parte I. — Torino, Stamperia Reale, 264 p. http://doi.org/ 10.5962/bhl.title.12269

BERnhARDT B. 1985: Mór-Bodajk. Magyarázó a Bakony hegység 20 000-es földtani térképsorozatához. — Budapest, Magyar Állami Földtani Intézet, $103 \mathrm{p}$.

BoetTGER, O. 1906: Zur Kenntnis der Fauna der mittelmiozanen Schichten von Kostej im Krasso-Szorenyer Komitat. III. Verhandlungen und Mitteilungen des siebenbürgischen Vereines für Naturwissenschaften zu Hermannstadt 54, 1-99.

Boury, E. de 1912: Catalogue raisonné de la collection de Scalaria vivants et fossiles du Muséum de Paris. — Nouvelles Archives du Muséum d'Histoire Naturelle 5/4, 209-266.

BrocCHI, G. 1814: Conchiologia fossile subapennina, con osservazioni geologiche sugli Apennini e sul suolo adiacente, 1-2. Stamperia Reale, Milano, $712 \mathrm{p}$.

BUdAI, T. \& FodOR, L. (eds) 2008: Geology of the Vértes Hills. Regional map series of Hungary. — Budapest, Geological Institute of Hungary, $368 \mathrm{p}$.

CRISTOFORI, J. de \& JAN, G. 1832. Cataloghi sistematici e descrittivi degli oggetti di storia naturale esistenti nel Museo di G. De Cristofori e Prof. G. Jan. Sectio II. Pars I. Conchylia fossilia. — Milano, Pirotta, 16 p. 
CSEPREGHY-Meznerics, I. 1954: A keletcserháti helvéti és tortónai fauna. (Helvetische und Tortonische fauna aus dem Östlichen Cserhátgebirge.) - Jahrbuch der Ungarischen Geologischen Anstalt 41/4, 1-185.

CSEPREGHY-MEZNERICS, I. 1956: Die Molluskenfauna von Szob und Letkés. — Jahrbuch der Ungarischen Geologischen Anstalt 45/2, 363-477.

CSEPREghY-MezNerics, I. 1969: Nouvelles Gastropodes et Lamellibranches pour la faune hongroise des gisements tortoniens-inférieurs de la Montagne de Bükk. - Annales Historico-Naturales Musei Nationalis Hungarici, Pars Mineralogica et Palaeontologica 61, 63-127.

CSEPREGHY-MeZnerics, I. 1970: Les formations tortonien inférieur de la Montagne de Bükk et la »nanno-faune de Bóta«. — Földtani Közlöny 100/3, 259-273. (In Hungarian with French abstract)

Dell'Angelo, B., Sosso, M., KroH, A. \& Dulai, A. 2015: Polyplacophora from the Eocene of Gánt, Hungary. — Bulletin of Geosciences 90/2, 359-370. http://doi.org/10.3140/bull.geosci.1517

Dolin, L. 1998: Description de trois espèces nouvelles de Cypraeidae et de Triviidae (Mollusca: Gastropoda) du Miocène inférieur (Aquitanien) de Meilhan (Landes, France). - Cossmanniana 5/3-4, 103-108.

Dulai, A. 2005: Badenian (Middle Miocene) Polyplacophora from the Central Paratethys (Bánd and Devecser, Bakony Mountains, Hungary). - Fragmenta Palaeontologica Hungarica 23, 29-49.

DulaI, A. 2007: Badenian (Middle Miocene) micromorphic brachiopods from Bánd and Devecser (Bakony Mountains, Hungary). Fragmenta Palaeontologica Hungarica, 24-25, 1-13.

Fense, D. 2010: New Species of fossil Cypraeoidea from Europe and Australia (Mollusca: Gastropoda). — Palaeontographica Abt. A 292/1-3, 1-19. http://doi.org/10.1127/pala/292/2010/1

FeHSE, D. \& Vicián, Z. 2004: A new Zonarina (Mollusca: Gastropoda: Cypraeidae) from the middle Miocene (Badenian) of Hungary. Földtani Közlöny 134/2, 201-208.

Fehse, D. \& Vicián, Z. 2006: A new Middle Miocene (Badenian) Trivia species (Mollusca: Gastropoda) from Borsodbóta (Hungary). Földtani Közlöny 136/2, 399-406.

FEHSE, D. \& VICIÁN, Z. 2008: On the identity of Projenneria neumayri (HILBER, 1879) with the description of a new species of the genus Projenneria Dolın, 1997 from the Badenian of the Central Paratethys (Mollusca: Gastropoda: Cypraeoidea). — Földtani Közlöny 138/4, 357-362.

Ferrero, M. \& Piccoli, G. 1970: L'evoluzione del genere Conus nel terziario Veneto. - Memorie degli Istituti di Geologia e Mineralogia dell'Universita di Padova 27, 1-34.

Ferrero Mortara, E., Montefameglio, L., Novelli, M., Opesso, G., Pavia, G. \& Tampieri, R. 1984: Catalogo dei tipi e degli esemplari figurati della collezione Bellardi e Sacco. Parte II. - Museo Regionale di Scienze Naturali, Torino, 484 p.

Goret, B. \& Pons, J. 2013: Les Muricidae (Gastropoda, Muricoidea) du Miocène de Montpeyroux (Hérault - France). — Palaeontos 23, 53-70.

GRATEloup, J. P. S. de 1833: Tableau des coquilles fossiles qu'on rencontre dans les terrains calcaire tertiaires grossiers (faluns) des environs de Dax, Département des Landes. - Actes de la Société Linnéenne de Bordeaux 6/33, 90-100.

Grateloup, J. P. S. de 1845-1846: Conchyliologie fossile des terrains tertiaires du Bassin de l'Adour (environs de Dax), 1. Univalves. Atlas. - Bordeaux, Lafargue, pls. 1-45 (1840), pp. 12, pls. 46-48 (1846).

Gregorio, A. de 1880: Fauna di San Giovanni Ilarione (Parisiano), Parte 1 ${ }^{a}$ : Cefalopodi e Gasteropodi. — Palermo, Montaina \& C., $106 \mathrm{p}$.

HaLl, C. A. 1966: Middle Miocene Conus (Class Gastropoda) from Piedmont, northern Italy. — Bollettino della Società Paleontologica Italiana, 3/2(1964), 111-171.

HÁMOR, G. 2001: Miocene paleogeography of the Carpathian Basin. — MÁFI, Budapest, 71 p.

HARZHAUSER, M. \& LANDAU, B. 2012: A revision of the Neogene Cancellariid Gastropods of the Paratethys Sea. —Zootaxa 3472, 71 p.

HARZHAUSER, M. \& LANDAU, B. 2016: A revision of the Neogene Conidae and Conorbidae (Gastropoda) of the Paratethys Sea. —Zootaxa 4210/1, pp. 178. http://doi.org/10.11646/zootaxa.4210.1.1

Harzhauser, M., LANDAu, B. \& Breitenberger, A. 2017: The false limpet Siphonaria in the circum-Tethyan Miocene with emphasis on its occurrence in the Paratethys Sea. — Annalen des Naturhistorischen Museums in Wien, Serie A, 119, 115-130.

Hegedús, Gy. \& JANKovich, I. 1972: Récif corallien du Badénien a Márkháza. — Jahresbericht der Ungarischen Geologischen Anstalt für 1970, 39-53 (In Hungarian with French abstract).

HILBER, V. 1879: Zur Fossilliste des Miocänfundortes Pöls in Steiermark. — Verhandlungen der k.k. Geologischen Reichsanstalt 2, $29-31$.

Hoernes, R. \& AuInger, M. 1879-1891: Die Gasteropoden der Meeres-Ablagerungen der ersten und zweiten Miocänen MediterranStufe in der Österreichisch-Ungarischen Monarchie. - Abhandlungen der k.k. geologischen Reichsanstalt 12, 1-382, 50 pls. Published in parts: 1-52, pls 1-6 (1879), 53-112, pls 7-12 (1880), 113-152, pls 13-16 (1882), 153-192, pls 17-22 (1884), 193-232, pls 23-28 (1885), 233-282, pls 29-36 (1890), 283-330, pls 37-42 (1891), 331-382, pls 43-50 (1891).

HörNES, M. 1851-1870. Die fossilen Mollusken des Tertiär-Beckens von Wien. — Abhandlungen der Kaiserlich-Königlichen Geologischen Reichsanstalt, 3-4, 1-42, pl. 1-5 (1851), 43-208, pl. 6-20 (1852), 209-296, pl. 21-32 (1853), 297-382, pl. 33-40 (1854), 383-460, pl. 41-45 (1855), 461-736, pl. 46-52 (1856) (3); 1-479, pls 1-85 (1870) (4).

JAKus P. 1980: Márkó. Magyarázó a Bakony hegység 20 000-es földtani térképsorozatához. — Budapest, Magyar Állami Földtani Intézet, $58 \mathrm{p}$.

KeCSKEMÉTI T. 1998: Magyarország epikontinentális eocén képződményeinek rétegtana. — In: BÉRCZI I. \& JÁMBOR Á. (szerk.): Magyarország geológiai képződményeinek rétegtana. MOL Rt. és MÁFI, Budapest, 403-417.

KeCSKEMÉTI-KöRMENDY, A. 1980: Le faune des Mollusques du faciès de bassin éocène du Bakony nord-oriental. — Jahrbuch der Ungarischen Geologischen Anstalt 63/3, 1-227. 
Kecskeméti-KöRmendy, A. \& MÉszÁros, N. 1980: Mollusques éocènes du secteur oriental de la montagne du Bakony (faciès archipélagique). — Jahrbuch der Ungarischen Geologischen Anstalt 63/2, 1-143.

KNAUER J. \& KoPEK G. 1982: Dudar. Magyarázó a Bakony hegység 20 000-es földtani térképsorozatához. —-Budapest, Magyar Állami Földtani Intézet, 59 p.

KoJumdgieva, E. 1960: Le Tortonien du type viennois. — In: KoJumdgIEVA, E. \& Strachimirov, B. 1960: Les fossiles de Bulgarie, VII, Tortonien, 1-246, Academie des Sciences de Bulgarie, Sofia, 317 p.

KóKAY, J. 1966: Geologische und paläontologische Untersuchung des Braunkohlengebietes von Herend-Márkó (Bakony-Gebirge, Ungarn). - Geologica Hungarica, series Palaeontologica 36, 1-147.

KovÁcs, Z. \& BALÁzs, P. 2016: Conidae (Neogastropoda) assemblage from the Middle Miocene of the Făget Basin (Romania) in the collection of the Hungarian Natural History Museum, Budapest. — Fragmenta Palaeontologica Hungarica, 32(2015), 11-48.

KovÁcs, Z. \& Vicıán, Z. 2014: Badenian (Middle Miocene) Conoidean (Neogastropoda) fauna from Letkés (N Hungary). — Fragmenta Palaeontologica Hungarica 30(2013), 53-100.

KovÁcs, Z. \& ViCiÁn, Z. 2016: A new Egerian (Upper Oligocene - Lower Miocene) gastropod fauna from the Esztergom Basin (NE Transdanubia, Hungary). — Földtani Közlöny 146/3, 233-255.

KovÁcs, Z. \& VicıÁn, Z. in press : Middle Miocene Tonnoidea and Ficoidea (Caenogastropoda) assemblages from Letkés (Hungary). — (Fragmenta Palaeontologica Hungarica).

KronenberG, G. C. \& Harzhauser, M. 2012: Europrotomus (Mollusca: Caenogastropoda: Strombidae): a new Middle Miocene European strombid genus (Revision of Euprotomus Gill, 1870. Part 4). — Paläontologische Zeitschrift 86/2, 147-159. https://doi.org/ 10.1007/s12542-011-0121-1

Landau, B., Harzhauser, M., BüYüKMeriç, Y. \& BreItenberger, A. 2016: Additions to the gastropods of the middle Miocene (Serravallian) Karaman Basin, Turkey. — Cainozoic Research 16/2, 221-229.

Landau, B., Harzhauser, M., İslamoĞLU, Y. \& Silva, C. M. 2013: Systematics and palaeobiogeography of the gastropods of the middle Miocene (Serravallian) Karaman Basin, Turkey. — Cainozoic Research 11-13, pp. 584.

Landau, B., Hount, R. \& Silva, C. M. 2007: The Early Pliocene Gastropoda (Mollusca) of Estepona, Southern Spain. - Palaeontos 11, $1-87$.

LoRENZ, F. 2014: Monograph of the genus Pustularia (Gastropoda: Cypraeidae). — Harxheim, ConchBooks, 130 p.

Merle, D., Garrigues, B. \& Pointier, J.-P. 2011: Fossil and Recent Muricidae of the World. Part Muricinae. - ConchBooks, 648 p.

MichelotTI, G. 1841: Monografia del genere Murex ossia enumerazione delle principali specie dei terreni sopracretacei dell'Italia. Vicenza, Tremeschin, $27 \mathrm{p}$.

Michelotтi, G. 1847: Déscription des fossiles des terrains Miocénes de l'Italie septentrionale. — Natuurkundige Verhandelingen van de Hollandsche Maatschappij der Wetenschappen te Haarlem 3/2, 408 p.

Mihály, S. \& VinCZE, P. 1984: New paleoecological remarks concerning the Middle Eocene beds of the Bagoly-hegy at Gánt, Transdanubia, Hungary. — Földtani Közlöny 114/3, 263-283. (in Hungarian with English abstract)

Millet DE LA TURTAUDIÈRE, P.-A. 1865: Indicateur du Maine-et-Loire ou indications par commune de ce que chacune d'elles renferme, 2. - Angers, Cosnier et Lachèse, 616 p.

Moissette, P., Dulai, A. \& Müller, P. 2007: Bryozoan faunas in the Middle Miocene of Hungary: biodiversity and biogeography. Palaeogeography, Palaeoclimatology, Palaeoecology 233(2006), 300-314. http://doi.org/ 10.1016/ j.palaeo.2005.10.001

NoszKY, J. 1925: Beiträge zur Fauna der Ungarischen Leithakalkbildungen. _ Annales Musei Nationalis Hungarici, Pars Mineralogica, Geologica, Palaeontologica 22, 230-280.

Noszky, J. 1936: Az egri felső cattien molluszkafaunája. [Die Molluskenfauna des oberen Cattiens von Eger.] — Annales Musei Nationalis Hungarici 30, 53-115.

NoszKY, J. 1940: A Cserháthegység földtani viszonyai. (Die Geologie des Cserhát-Gebirges.) — Geologische Beschreibung Ungarischer Landschaften 3, 1-178, (179-283).

Orbigny, A. d' 1852: Prodrome de paléontologie stratigraphique universelle des animaux mollusques et rayonnés, faisant suite au cours élémentaire de paléontologie et de géologie stratigraphique, 3. — Paris (Victor Masson): 196 p., index 189 p.

Ozsvárt P. 2007: Dudar. — In: PÁlfy J. \& PAZONYI P. (szerk.): Őslénytani kirándulások Magyarországon és Erdélyben. Budapest, Hantken Kiadó, 92-93.

Sacco, F. 1890: I Molluschi dei terreni terziarii del Piemonte e della Liguria. Parte 7. — Torino, Clausen, 96 p. http://doi.org/10.5962/ bhl.title.12269

SACCO, F. 1891: I Molluschi dei terreni terziarii del Piemonte e della Liguria. Parte 9. — Torino, Clausen, 102 p. http://doi.org/10.5962/ bhl.title.12269

SACCO, F. 1893: I Molluschi dei terreni terziarii del Piemonte e della Liguria. Parte 13. _ Memorie della Reale Accademia delle scienze di Torino, 44, 143 p. http://doi.org/10.5962/bhl.title.12269

SACCO, F. 1904: I Molluschi dei terreni terziarii del Piemonte e della Liguria. Parte 30. — Torino, Clausen, 203 p. http://doi.org/10.5962/ bhl.title.12269

Stein, G., Moths, H., Albrecht, F., Havekost, U. \& Fehse, D. 2016: Revision der miozänen Molluskenfauna (Hemmoorium) von Werder bei Achim (Nordwest-Niedersachsen). — Palaeofocus 5, 1-289.

Stojaspal, F. 1978: Muricidae. - In: Papp, A., CiCha, I., Seneš, J. \& Steininger, F. 1978: M4 Badenien. Chronostratigraphie und Neostratotypen 6, Bratislava, Veda, 333-340,

STRAUSZ, L. 1962: Über die paläoökologischen Verhältnisse der Eozänfauna von Gánt. — Földtani Közlöny 92/3, 308-318.

STRausz, L. 1966a: Die Eozängastropoden von Dudar in Ungarn. — Geologica Hungarica series Palaeontologica 33, 1-199.

STRAUSZ, L. 1966b: Die miozän-mediterranen Gastropoden Ungarns. — Budapest, Akadémiai Kiadó, 692 p. 
STRAUSZ, L. 1969: Über Kleinmollusken aus dem Mittel-Eozän von Dudar. — Földtani Közlöny 99/2, 147-154.

SzŐTs, E. 1953: Mollusques Éocènes de la Hongrie I. Les mollusques éocènes des environs de Gánt. — Geologica Hungarica series Palaeontologica 22, $241 \mathrm{p}$.

SzŐTs, E. 1956: L’Éocène (Paléogène) de la Hongrie. — Geologica Hungarica, series Geologica 9, 318 p.

SzTANÓ, O., Magyari, Á. \& NAGYMAROSY, A. 1998: High-resolution stratigraphy in the Esztergom Basin, northeastern Transdanubia, Hungary: II. Oligocene sequences and their interpretation. — Földtani Közlöny 128/2-3, 455-486 (in Hungarian with English abstract)

VermeIJ, G. J. \& VoKes, E. H. 1997: Cenozoic Muricidae of the Western Atlantic Region. Part XII - the Subfamily Ocinebrinae (in part). - Tulane Studies in Geology and Paleontology 29/3, 69-118.

VoKes, E. H. 1971: Catalogue of the Genus Murex Linné (Mollusca: Gastropoda); Muricinae, Ocenebrinae. — Bulletins of American Paleontology 61/268, 5-141.

VOKES, E. H. 1978: Muricidae (Mollusca: Gastropoda) from the eastern coast of Africa. — Annals of the Natal Museum 23/2, 375-418.

VoKes, E. H. 1994: Cenozoic Muricidae of the Western Atlantic Region. Part X - the Subfamily Muricopsinae. - Tulane Studies in Geology and Paleontology 26/2-4, 49-160.

ZILCH, A. 1934: Zur Fauna des Mittel-Miocans von Kostej (Banat); Typus Bestimmung und Tafeln zu O. Boettger's Bearbeitungen. Senckenbergiana 16, 193-302.

Kézirat beérkezett: 2017. 03. 30.

\section{Plate 1 - I. tábla*}

1-2. Europrotomus schroeckingeri (HÖRNES in HOERNES \& AUINGER), SL 45, MD 28 (1.3×), Márkháza, collection NÁDAI.

3-4. Xenophora italica (GRATELOUP), SL 70, MD 80 (1×), Letkés, collection VICIÁN.

5-7. Eopustularia balinka FEHSE, SL 19, MD 12 (2.5×), Gánt, collection VICIÁN.

8-9. Eopustularia balinka FeHSE, SL 20, MD 12.5 (2.2×), Balinka, collection VICIÁN.

10-12. Propustularia neugeboreni (HOERNES et AUINGER), SL 23, MD 13.5 (2.2×), Márkháza, collection ViciáN.

13-14. Cassis postmamillaris SACCO, SL 83, MD 65 (1×), Letkés, collection HIRMETZL.

15-16. Sthenorytis cf. pseudoretusa (SACCO), SL 15, MD 13 (2.5×), Esztergom, HNHM INV 2017.302.

7. Morum cythara (BROCCHI), SL 31, MD 20.5 (1.5×), Eger, collection NÉMETH.

*Shell length (SL) and maximum diameter (MD) in mm. Photographs without indication made by Z. KováCs. 
Plate 1 - 1. tábla

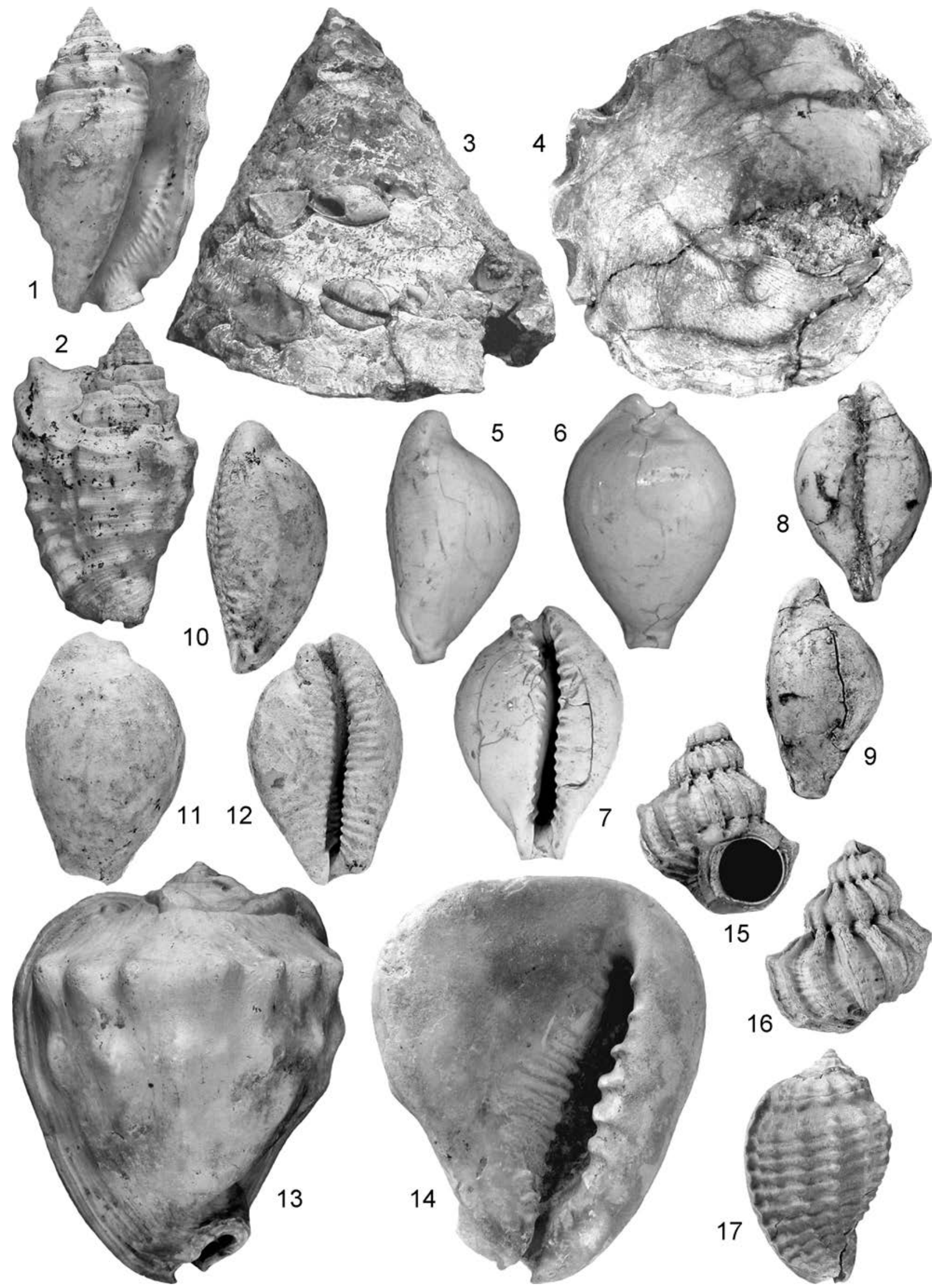


Plate 2-2. tábla

1-2. Pterynotus granuliferus (GRATELOUP), SL 47, MD 28 (1.6×), Letkés, collection HIRMETZL.

3-4. Purpurellus cyclopterus (MILLET), SL 45, MD 24 (1.7×), Letkés, collection HIRMETZL.

5-6. Dermomurex (s.s.) distinctus (CRISTOFORI et JAN), SL 10, MD 5.2 (3×), Letkés, collection KovÁCS.

7-8. Dermomurex (s.s.) distinctus (CRISTOFORI et JAN), SL 15, MD 9 (2.5×), Letkés, collection Kovács.

9-10. Favartia (Pygmaepterys) transsylvanica (HOERNES et AUINGER), SL 12.5, MD 6 (3.5×), Bánd, collection ViCIÁN.

1-12. Ocinebrina kojumdgievae (BAŁUK), SL 31, MD 20 (2×), Márkháza, collection HIRMETZL.

13-14. Ceratostoma subaustriaca (STOJASPAL), SL 52, MD 35 (1.2×), Letkés, collection HiRMETZL.

15-16. Murexsul sandbergeri (HöRNES), SL 34, MD 20.5 (2×), Letkés, collection HIRMETZL.

7-18. Subpterynotus graniferus (MiCHELOTTI), SL 33, MD 21 (2×), Letkés, collection HIRMETZL.

19. Tripterotyphis wenzelidesi (HÖRNES), SL 6.3, MD 3.2 (9x), Letkés, collection KROCK (photo: G. STEIN).

20-21. Coralliophila gracilispira BoEtTGER, SL 9.5, MD 5.2 (6×), Márkháza, collection Krock (photo: G. STEIN). 
Plate 2 - 2. tábla

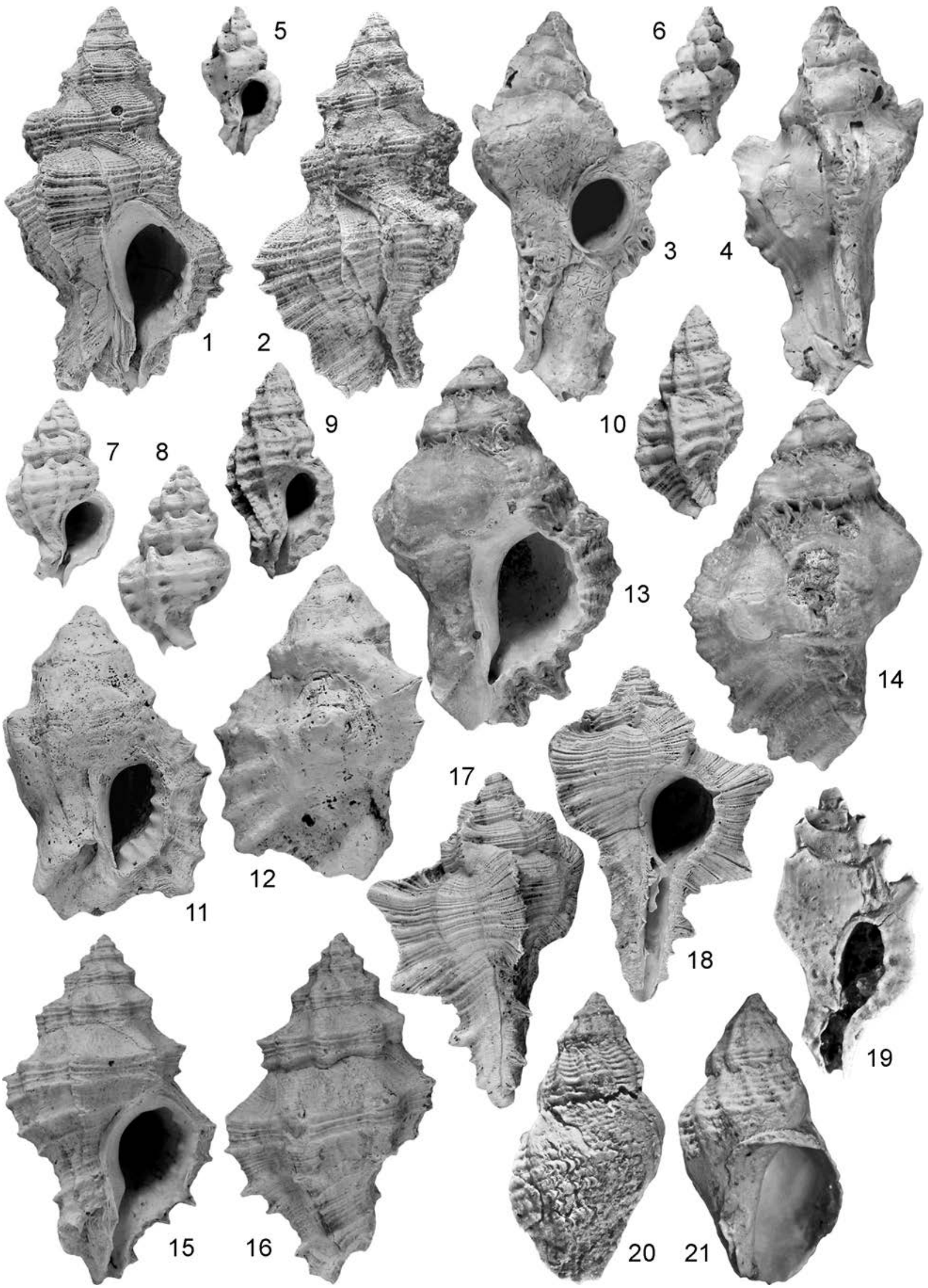


Plate 3-3. tábla

1. Aplus varians (MichelotTI), SL 13, MD 5.4 (4×), Letkés, collection Krock (photo: G. STEIN).

2. Aplus varians (MichelotTI), SL 14.1, MD 5.2 (4×), Bánd, collection KROcK (photo: G. STEIN).

3. Aplus varians (MichelotTI), SL 13.4, MD 5.1 (4×), Márkháza, collection KrocK (photo: G. STEIN).

4-5. Metula submitraeformis (D’ORBIGNY), SL 32, MD 10.9 (2×), Letkés, collection Krock (photo: G. STEIN).

6-7. Colubraria subobscura (HoERnEs et AUINGER), SL 36, MD 15.2 (1.6×), Letkés, collection HIRMETZL.

8-9. Colubraria subobscura (HoERnES et AUINGER), SL 16.5, MD 6.8 (3×), Letkés, collection Krock (photo: G. STEIN).

10. Scalptia neugeboreni (HöRNES), SL 15, MD 9 (4×), Letkés, collection KROCK (photo: G. STEIN).

11-12. Eoconus cf. conotruncus (DE GREGORIO), SL 40 (1.5×), Dudar, collection ViciáN.

13-14. Lautoconus oboesus (MichELOTTI), SL 44 MD 22 (1.5×), Letkés, HNHM INV 2017.303.

15-16. Lautoconus? praelongus (HOERNES et AUINGER), SL 27, MD 11.5 (2×), Letkés, collection KovÁcs.

17-18. Lautoconus harzhauseri KovÁCs nov. sp., holotype, SL 48, MD 28 (1.2×), Letkés, HNHM PAL 2017.49.

19-20. Lautoconus harzhauseri KovÁCs nov. sp., $1^{\text {st }}$ paratype, SL 53, MD 30 (1.2×), Letkés, HNHM PAL 2017.50.

21. Lautoconus harzhauseri KovÁcs nov. sp., SL 42, MD 25 (1.2×), Letkés, collection KovÁcs.

22. Clathurella vasta (BOETTGER), SL 8.2, MD 4.3 (7×), Borsodbóta, collection KrocK (photo: G. STEIN). 


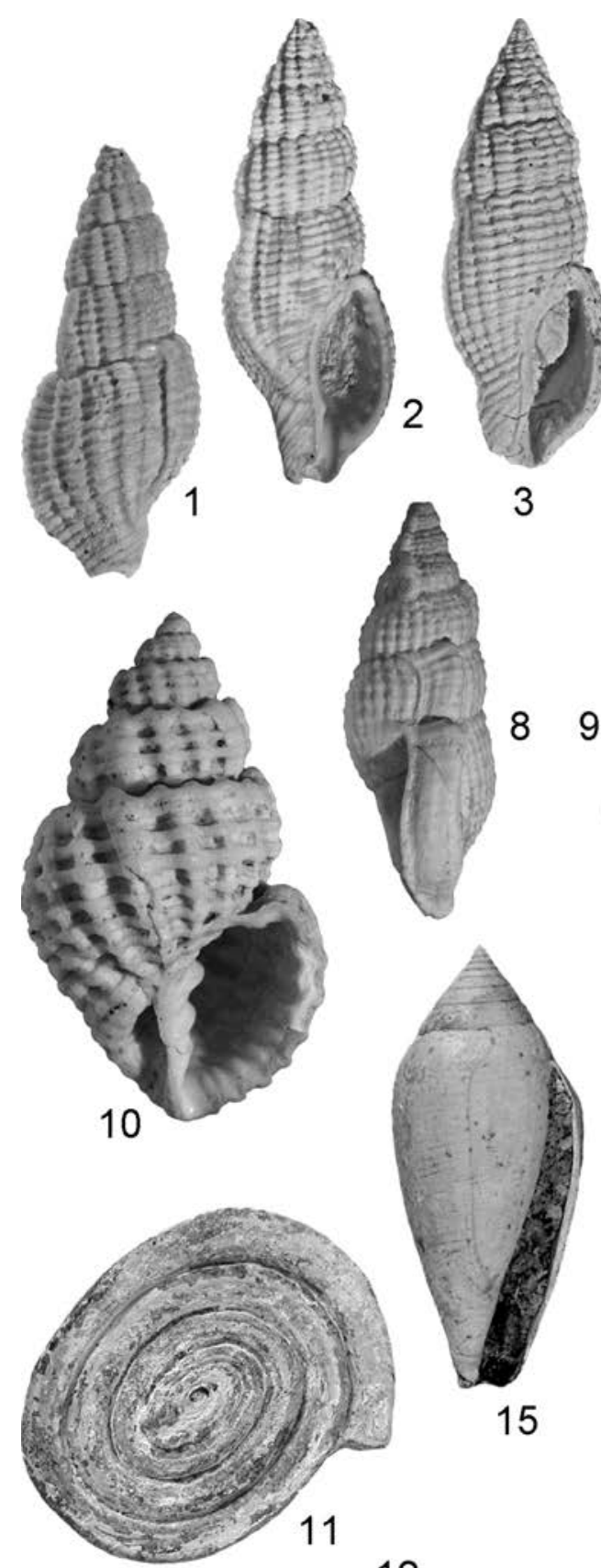

Plate 3-3. tábla
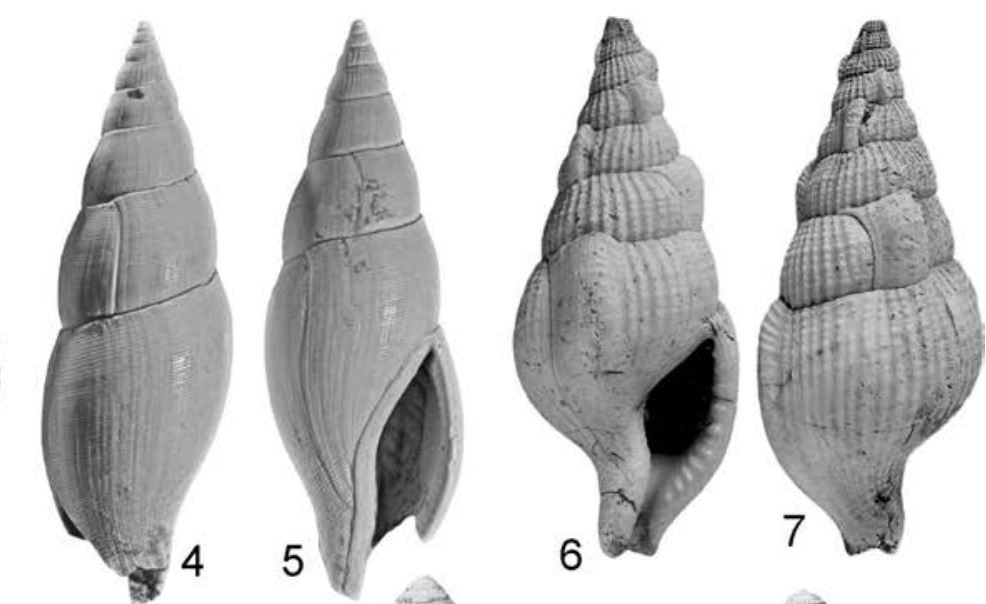

12
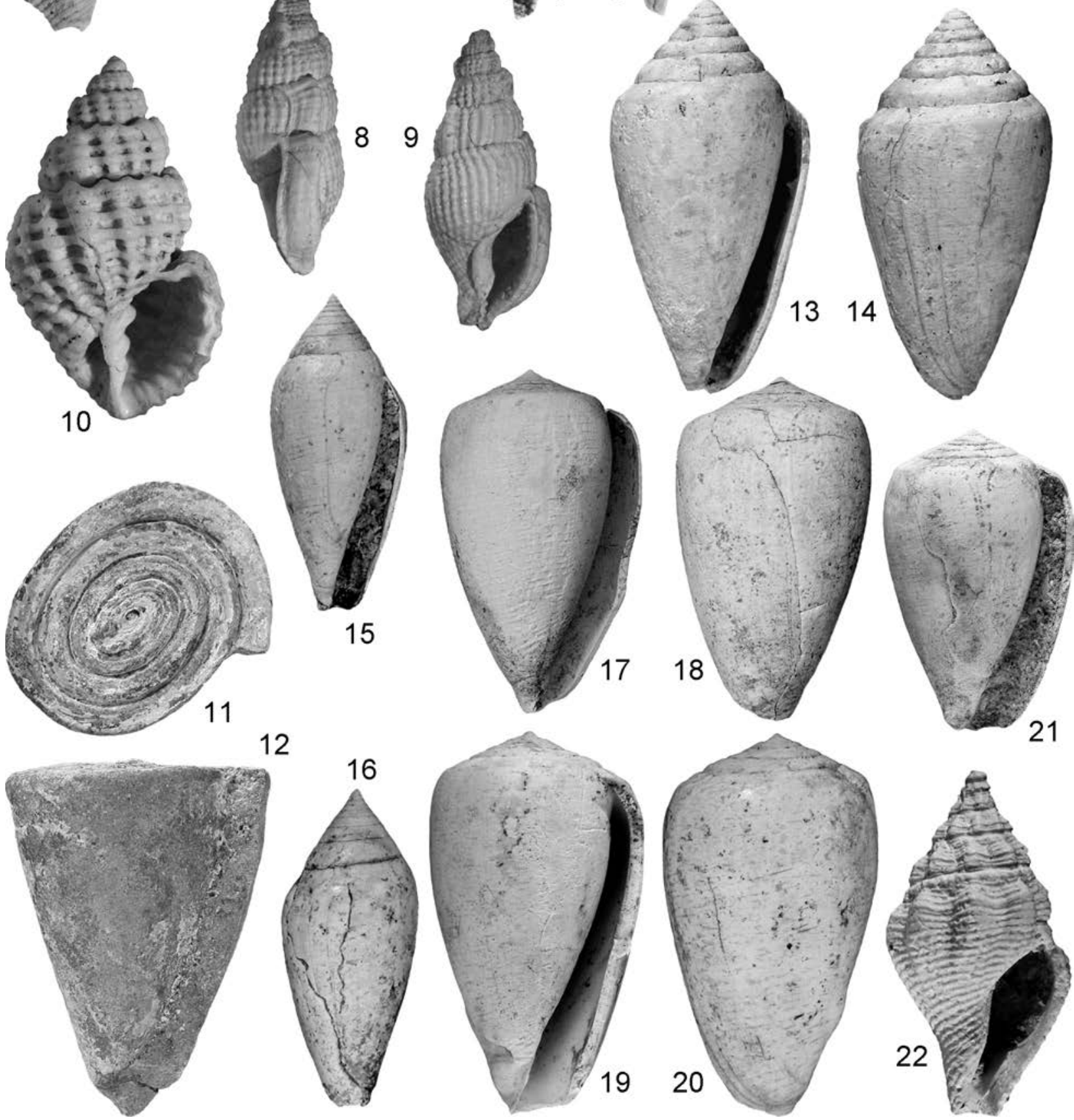
